\title{
Linking the cultural capital of the entrepreneur and early performance of new ventures: A cross-country comparison
}

\author{
Malgorzata A. Wdowiak, Erich J. Schwarz, Robert J. Breitenecker, \\ Richard W. Wright
}

We explore the impact of an entrepreneur's cultural capital on the performance of new ventures in both mature and transition economies. Results show that individualistic values of the founder influence early performance of new ventures, irrespective of the country context; and that in less advanced transition economies, the entrepreneur's cultural-background profile has a stronger influence on new venture performance than education or industry experience. Our findings support the assumption that entrepreneurial performance in new ventures is culture-driven, and suggest that economic analyses of entrepreneurial actions should encompass cultural values as well.

In unserer Studie untersuchen wir den Einfluss des individuellen Kulturkapitals auf den Erfolg der Neugründungen in traditionellen und entstehenden Marktwirtschaften Europas. Die Ergebnisse zeigen, dass unabhängig vom Landeskontext individualistische Werte der Gründer den Unternehmenserfolg signifikant beeinflussen. In weniger fortgeschrittenen Transformationswirtschaften hat der kulturelle Hintergrund des ökonomischen Akteurs einen stärkeren Einfluss auf den Unternehmenserfolg als traditionelle Humankapitalgrößen wie Branchenerfahrung oder Ausbildung. Unsere Ergebnisse unterstützen die Annahme, dass der Erfolg von Neugründungen kulturell bedingt ist und dass diese Aspekte in die Entrepreneurship-Forschung besser integriert werden sollten.

Keywords: entrepreneurship; new venture performance; cultural capital; transition economy; Slovenia; Poland; Austria.

Manuscript received: 11.10.10, accepted: 05.11 .11 (1 revision)

** Malgorzata A. Wdowiak, Klagenfurt University, Department of Innovation Management and Entrepreneurship, Austria. Main research areas: Philosophy and economics, cultural economics, economic sociology, entrepreneurship, intercultural and international management. Corresponding address: malgorzata.wdowiak@aau.at

Erich J. Schwarz, Klagenfurt University, Department of Innovation Management and Entrepreneurship. Main research areas: Young, innovative SMEs, integration of customers into the innovation process, business models and success factors of new ventures.

Robert J. Breitenecker, Klagenfurt University, Department of Innovation Management and Entrepreneurship. Main research areas: Spatial and multivariate statistical methods, innovation management and entrepreneurship.

Richard W. Wright, Klagenfurt University, Department of Innovation Management and Entrepreneurship. Main research areas: globalisation and international businesses, particularly with regard to the Asian markets. 


\section{Introduction}

Development of new ventures is of paramount importance for market economies (Lyles et al. 2004; Smallbone/Welter 2001). Therefore, success factors of newventure performance have received extensive attention since the beginning of the 1980s (Bosma et al. 2004; Brüderl et al.1998; Gartner 1985). Numerous studies have focused on the entrepreneur who creates the venture under conditions of high uncertainty due to the liabilities of newness and smallness (e.g. Davidsson/Honig 2003; Cooper et al.1994).

Previous research has devoted considerable attention to understanding the significance of the individual's investments in human capital, such as education or job training for organizational outcomes (Kennedy/Drennan 2001). But most studies have neglected the cultural background of the entrepreneur. Furthermore, most of them have focused on the United States and Western Europe, with abundant resources, entrepreneurial role models and stable institutional environments. The situation of entrepreneurs creating their ventures in emerging economies with scarce resources, unstable institutions and a limited entrepreneurship tradition remains under-researched (Schwarz/Wdowiak 2006; Lyles et al. 2004). Especially in the context of transition environments, individual's values and habits (e.g. ability to handle scarce resources) may be crucial determinants of entrepreneur's outcomes.

A relevant research question is how to extend the existing models to encompass cultural dimensions, and to make them applicable to less-developed market economies.

In this paper we discuss the impact of the founder's cultural capital on early performance of new ventures in both emerging and mature economies; and we test whether the same factors affect new venture performance similarly in both markets. We argue that the assumption of self-interest, opportunistic and individualistic behavior in entrepreneurial context may not be universal (Bruton et al. 2008). We also examine the disparities in influence factors between distinct emerging economies. Our research context for emerging market economies are those in transition from centrally-planned toward free market, such as post-communist countries in Central and Eastern Europe. ${ }^{1}$

In the study, we apply Bourdieu's theory of cultural capital. Following his approach, analyses of the determinants of an individual's outcomes also have to consider assets such as skills, values, or practices previously acquired through the socialization processes in the family and in school; i.e. cultural capital acquired early in life (Bourdieu 1986). In transition economies with unstable environments and a short period of financial accumulation in private

1 Emerging markets encompass a wide range of countries including, but not limited to, those that are in transition from communism. Another example of emerging markets are countries that previously have had some democratic institutions in connection with strong governmental control of the economy and are now liberalizing, such as India and Turkey. 
households, the entrepreneurial process is determined primarily by the founder's abilities, knowledge, and values. Furthermore, because business and vocational education in transition countries has not yet reached the levels of mature economies (Münich et al. 2005), we can expect that the return of education under communism and during the early transition is lower in an entrepreneurial context. Consequently, the competences, skills and values of the entrepreneur may be seen as crucial resources of the entrepreneur within that cultural context. We therefore investigated direct and indirect effects of cultural values, entrepreneurial skills, industry experience, and education on entrepreneurial outcomes.

We tested our model in three countries at different stages of economic development: Austria, Poland and Slovenia. Austria, with 2005 GDP per capita of US\$ 36,980 (World Bank 2006), represents mature economies with abundant resources and stable institutions. Slovenia, as the wealthiest country among European emerging markets (GDP per capita: US\$ 17,350) embodies advanced transition economies, while Poland (GDP per capita of US\$ 7,943) represents middle-advanced transition economies. The research is based on a written survey conducted in January 2007 among new ventures (Austria: $n=170$, Poland: $n=167$, Slovenia: $n=352$ ) created on average six months before collecting the data, enabling us to identify influence factors on a venture's performance in the early months of its existence.

We contribute conceptually to previous research on new venture performance by extending the discussion about embodied capital of the founder from human capital to cultural capital. In the context of early performance, it seems to be essential to capture the individual under a cultural umbrella. Further, the study seeks to contribute to the better understanding of the entrepreneur's cultural background in different economic environments.

In the first section of this paper, we outline the theoretical background of the analysis and the results of previous empirical research. Then we develop and explain our investigated hypotheses. We follow with the details of the methodology chosen for the study and present the results of the analysis. Finally we discuss the findings, conclusions and implications for future research.

\section{Cultural capital in an entrepreneurial context}

\section{Theoretical background}

New ventures are exposed to a high risk of failure because of the liabilities of newness and smallness (Cooper et al. 1994). Additionally, in transition economies, the hostile environment in terms of weak institutional frameworks and limited availability of capital makes survival of new ventures even more challenging (Lyles et al. 2004). The initial stock of resources of a new enterprise is crucial to its survival and early growth, irrespective of environmental conditions. It provides a buffer that helps the new venture overcome the 
liabilities of newness (Cooper et al. 1994) and provides a "positive feedback dynamic in the resource accumulation process in which initial advantages amplify over time" (Shane/Stuart 2002: 154). Resources can be provided through an initial stock of the entrepreneur's capital (Ndofor/Priem 2005). Capital can be treated as power "over the accumulated product of past labor ... and thereby over the mechanisms which tend to ensure the production of a particular category of goods and thus over a set of revenues and profits" (Bourdieu 1991: 230). ${ }^{2}$ Bourdieu identifies a wide range of types of capital that constitute power resources, particularly the cultural, social and economic capital of the individual that can be converted into corporate resources and other forms of economic payoffs. Following the theory of early growth of a firm, the cultural capital of the founder seems crucial to the success of a newly founded business: 'In new firms, the entrepreneurs' experience, personality, perceptions and resources are formative. The founder or founding group not only shapes initial conditions but also provides the venture with its essential assets and impetus. Their ambitions determine whether there will be an early drive for growth or modest aspirations for the firm" (Garnsey 1998: 530). We explore the contribution of the founder's cultural capital to the venture's performance in the early phases of venture development, when the social networks of an emerging organization (customers, suppliers and investors) and its economic resources are very limited.

Cultural capital comprises the individual's institutionalized capital, such as occupational certificates, education diplomas and academic degrees, and the individual's incorporated capital, for example competences, skills and habits consisting of cultural values and behavioral routines (Bourdieu 1986: 243-248). ${ }^{3}$ For Bourdieu, the incorporated cultural capital is the most relevant for individuals' actions and outcomes (Bourdieu 1986: 244).

Cultural capital appears to share some similarities with human capital components. Therefore, it is vital to understand where the boundaries between human and cultural capital theories lie. A most essential distinction between cultural and human capital theories refers to the different ontological premises about the nature of individual behavior. Contrary to human capital representatives, Bourdieu does not share the assumption of a rational-actor approach. Becker (1993: 17) states that investments in human capital "usually are rational responses to a calculus of expected costs and benefits". Bourdieu (1986) argues that the choices of individuals are more tacit, practical and dispositional. They reflect both the accumulated capital from past life and work experience of the individual and the present opportunities and constraints of the

For an extensive discussion of the term "capital", see Dean and Kretschmer (2007).

3 Bourdieu (1986) also distinguishes an objectified cultural capital that refers to material objects an individual possesses, such as a CD player, computer, paintings or books. Because we focus primarily on capital dimensions embodied in the individual itself, we exclude objectified capital from our analysis. 
field in which they act. The accumulation of cultural capital in its embodied form begins in early childhood by "pedagogical actions" of parents, other family members or hired professionals (Swartz 1997: 76). These actions may pass unnoticed at that time, but they constitute the central mechanisms by which individual outcomes are determined (Clausen 1968).

Bourdieu (1986: 243) criticizes proponents of human capital theories, stating that their discourse of individual productivity is usually reduced to "monetary investments and profits, or those [investments] directly convertible into money, such as the costs of schooling and the cash equivalent of time devoted to study". Subtle dimensions of cultural socialization, which usually cannot be easily quantified in monetary terms, are disregarded in human capital theories. Through cultural socialization people can adopt to their environment in nongenetic ways. It provides them with assets such as moral norms, cultural values or language which are necessary for acting and participating within their society (Clausen 1968). Thus, important cultural investments prior to transition into adulthood remain neglected in human capital concept: "They [human capital theoreticians] inevitably, by a necessary paradox, let slip the best hidden and socially most determinant educational investment, namely the domestic transition of cultural capital" (Bourdieu 1986: 244).

An additional difference between human and cultural capital lies in the origin of capital. Both forms of capital are embodied in the economic actor, but cultural capital is partly accumulated through the (unconscious) transfer of cultural assets from one to the next generation within a family and may therefore be considered to a certain degree family-embedded and collectively-inherited. On the other hand, accumulation of human capital mostly occurs as a result of idiosyncratic, calculated (conscious) investments (Robinson et al. 2002).

Bourdieu's concept of cultural capital emerged initially from his research to explain unequal scholastic achievement and has been applied in other educational studies (Mohr/DiMaggio 1995; Sullivan 2001). His premise that culture cannot be ignored in studies of stratification has been widely applied in other contexts as well, for example, in research on sporting achievements, occupational success and national poverty (for critical analysis, see Schwartz/Zolberg 2004). Recently, a few management scholars have attempted to implement his approach in the business sciences, recognizing the need to extend the logic of economic analysis to encompass apparently non-economic goods such as culture (Ndofor/Priem 2005).

\section{Previous research}

The importance of diverse dimensions of cultural capital on new venture performance in mature economies is well recognized in entrepreneurship research. Previous studies focus primarily on the level of education, field of education, management experience, start-up experience, industry experience and entrepreneurial training (Schwarz et al. 2005; Davidsson/Honig 2003; Brüderl et 
al. 1998; Cooper et al. 1994). However, empirical results related to the influence of these factors on a firm's performance remain inconclusive. For example, Cooper, Gimeno and Woo (1994) observed a positive impact of education level on US new venture performance contrary to Stuart and Abetti (1990), who reported a negative correlation. Dunkelberg et al. (1987) again found a nonsignificant influence of entrepreneurs' investment in education on US new venture growth. Kennedy and Drennan (2001) conducted a meta-analysis of the impact of the founder's education and experience on a firm's performance. Of the 28 studies on the role of educational level in the entrepreneurial process 14 confirm a positive impact, whereas five report a negative relationship. Inconsistent findings may result to some extent from the differences in the samples or the methods of the studies. With respect to business and entrepreneurial education, the results are clearer: only one study reported a negative correlation between business education and performance. This literature review indicates also that founders' entrepreneurial and relatedbusiness experience correlate positively with their new venture performance.

Cultural values have received limited attention in research on entrepreneurial behavior and outcomes (Morris/Schindehutte 2005). Values are defined as "concepts or beliefs that pertain to desirable end states or behaviors and transcend specific situations in guiding selection or evaluation of behavior and events and are ordered by relative importance" (Schwartz 1992: 4). They can be viewed as a "mind map" of an individual, which serves as a set of guiding principles in his/her life (Schwartz 1994). Therefore, it has to be assumed that personal values are reflected in human behavior (Kilby 1993). ${ }^{4}$ Most of the value-based research in entrepreneurship has focused on the impact of culture on entrepreneurial activities at the macro-level (Hunt/Levie 2003; Wennekers et al. 2002). Nations with a higher level of individualism, masculinity and authority, and a lower level of power distance and uncertainty avoidance, seem to create more supportive conditions for entrepreneurship and innovation (Wennekers et al. 2002; Shane 1993). But few researchers have discussed the impact of cultural values on entrepreneurial performance at the micro-level (Morris/Schindehutte 2005; Tiessen 1997). We can expect that cultural values such as individualism, competitiveness, hard work and material gain affect entrepreneurial behavior in Western Europe. But countries in Central and Eastern Europe, which are still in transition toward free-market economies, may remain influenced by the more collectivistic values that prevailed during communism, such as the integration of individuals into the extended family and community, strong reciprocal relationships based on mutual favors, and a preference for equality.

4 As Lindeman and Verkasalo (2005: 178) state: "Values ... are inherently linked with personality, motivation, and behaviour, but they have a unique contribution for understanding any psychological phenomenon that somehow ties in with evaluation, justification, or selection of actions." 
Empirical studies dealing with the impact of cultural capital on new venture performance in transition economies are scarce. Wasilczuk (2000) provides insight into the role of education, experience, personal traits, and managerial skills on firm performance in a transition economy. She observed that entrepreneurs who have business and management experience delegate tasks more frequently, allocate more time to strategic planning, possess positive attitudes to risk-taking, and have a willingness to devote time to achieve success, and therefore experience favorable growth prospects. Lengyel (2002) also investigated the impact of values/habits reflecting communism's legacy - such as acceptance of norm-breaking behavior - on the success of Hungarian firms, and reported a negative effect.

It seems to be crucial to develop a model of the early performance of new ventures that deepens our knowledge of how the founder's cultural background affects entrepreneurial success in both mature and transition economies.

\section{Development of Hypotheses}

We developed a model of new venture performance in the early phases of the venture's emergence, using the concept of cultural capital from sociology (Fig. 1). Specifically, we investigate direct and indirect effects of cultural values, entrepreneurial skills, industry experience and education on entrepreneurial outcomes (early organizational performance and entrepreneur's satisfaction of being self-employed). The investigated hypotheses are discussed below.

Figure 1: Theoretical model

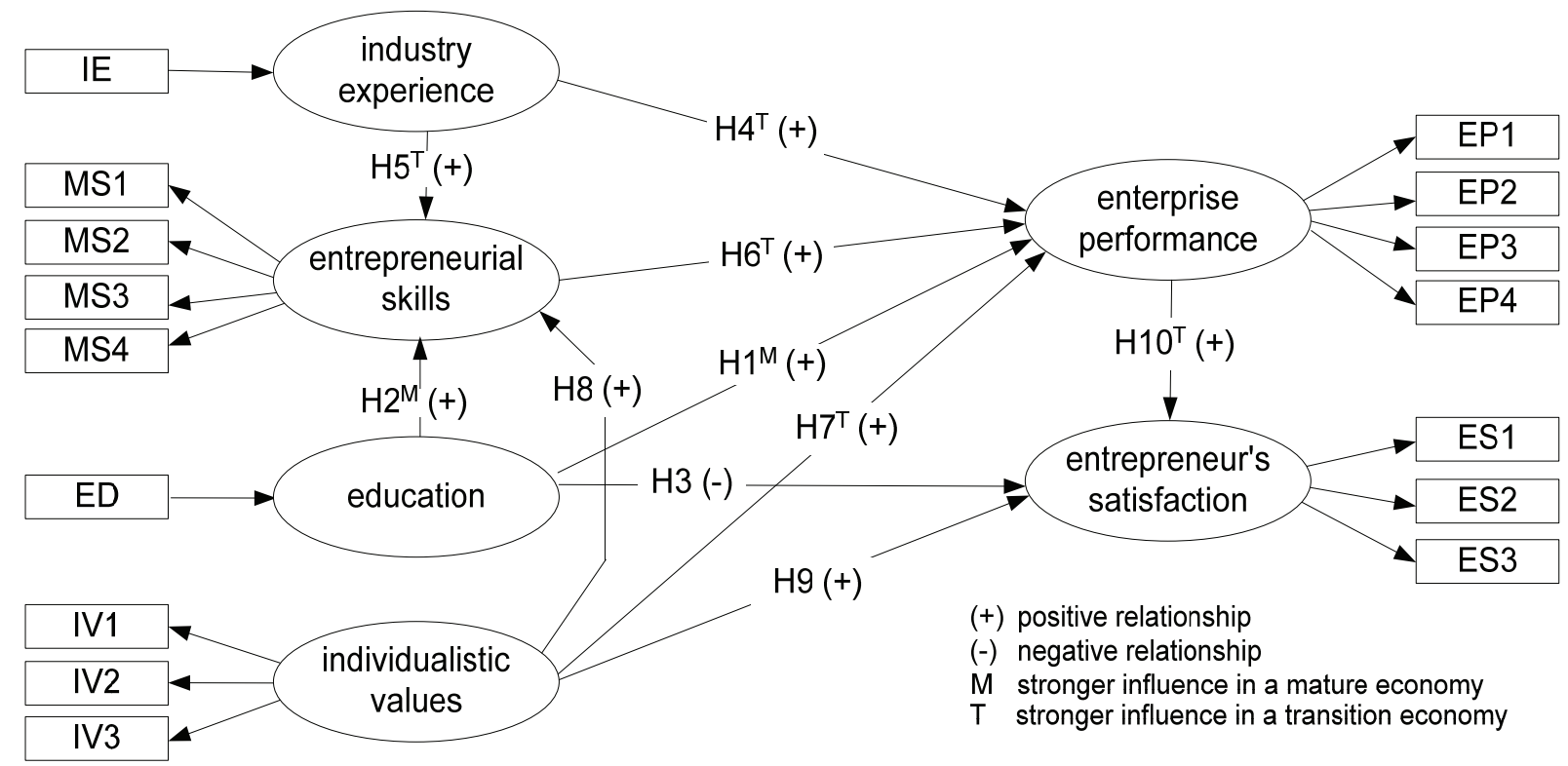




\section{Institutionalized Cultural Capital}

\section{Education}

Following cultural capital theory, entrepreneurs with higher levels of education are expected to perform better than others. With their investment in education, these entrepreneurs are generally more disciplined and self-confident, and have stronger analytical skills, a valuable knowledge base, and a better ability to make effective decisions (Bourdieu 1986). Acquired education is also a signal about the individual's talent and productivity (Weiss 1995). Entrepreneurs with a high investment in this type of capital are considered more trustworthy by clients, suppliers, investors and lenders. We also expect that the impact of educational level on new venture performance is stronger in Austria than in Poland and Slovenia, because of the differences in the programs of education. Particularly, in the beginning of the transition of post-communist countries, "courses leading to business, management, technical and specialized vocational qualifications were similar to those offered during the communist era" (Matlay 2001: 396). As individuals in the 25-44 years age group are mainly involved in entrepreneurial activity among the middle-income countries in Europe (Bosma et al. 2008), we can assume that most of the entrepreneurs in transition economies had graduated either late in the communist era or in the first decade of transition. Therefore, the education of entrepreneurs in transition economies may be less valuable in an entrepreneurial context than the education of their counterparts in mature economic systems. We hypothesize that:

H1: There will be a positive correlation between the educational level of the entrepreneur and enterprise performance.

Hla: The relationship between the educational level of entrepreneurs in (less advanced) transition economies and enterprise performance will be weaker than that of their counterparts in mature economies.

Further, we expect that the educational level of the entrepreneur has an indirect impact on new venture performance via entrepreneurial skills. We argue that well-educated individuals have a higher ability to recognize and to exploit new business opportunities because of their strongly developed analytical intelligence and their skills at making decisions efficiently. The Global Entrepreneurship Monitor (Bosma/Harding 2007) indicates that, worldwide, education beyond secondary school raises awareness of entrepreneurship to a larger degree than in primary and secondary schools, by offering entrepreneurship studies and by integrating courses on new venture creation into diverse business and technical disciplines. In post-communist Central and Eastern Europe, however, a large gap remains in the use of modern pedagogical concepts in providing an adequate knowledge of the principles of free-market economy and in encouraging creativity, independence and personal initiative among young people (Rebernik et al. 2004). The educational system under communism was not designed to encourage developing entrepreneurial skills. 
Economic systems characterized by stagnancy "place no premium for the human ability to deal with secular economic change" (Schultz 1975: 827). Even in the most advanced transition economy, Slovenia, universities still suffer from insufficient links with business, poor entrepreneurial infrastructure, and inadequate integration of small-business management into technical sciences (Rebernik et al. 2004). We developed the following hypotheses:

H2: There will be a positive correlation between the educational level and the entrepreneurial skills of the entrepreneur.

H2a: The relationship between the educational level and the entrepreneurial skills of entrepreneurs in (less advanced) transition economies will be weaker than that of their counterparts in mature economies.

Finally, we assume that the level of education has a negative impact on the entrepreneur's satisfaction of being self-employed. The higher the educational level, the higher the personal investments (costs) and simultaneously the higher the expected return on that capital (Becker 1993). In the labor market, wageemployment offers brighter prospects for high incomes and long-term job security than self-employment. Particularly in the early phases of a new venture, the prospect of achieving an adequate income is low and the risk of losing the capital invested in the business is high (Cooper et al. 1994). Furthermore, welleducated individuals may be more aware of the risks associated with entrepreneurship. Therefore, their satisfaction from being self-employed may be less than that of their counterparts with more limited career opportunities, irrespective of the country context (transition vs. traditional market economy). Therefore, we hypothesize that:

H3: There will be a negative correlation between an individual's educational level and his/her satisfaction of being an entrepreneur.

H3a: Their will be no significant country differences in the strength of the relationship between an individual's educational level and his/her satisfaction of being an entrepreneur.

\section{Incorporated Cultural Capital}

Industry experience

The impact of industry experience on new venture performance may be explained by the cultural capital theory. Occupational experience of the founder in the venture industry is to be viewed as capital that can be easily converted into economic resources of the enterprise (Bourdieu 1986). Entrepreneurs with industry experience possess specific market knowledge that enables them to better identify new business opportunities by understanding customer needs and problems, and to better exploit those opportunities by accumulating resources and formulating competitive strategies. Moreover, founders possessing industry experience are more likely to have networks of contacts with customers, suppliers, investors and advisers. Existing contacts in industry facilitate 
acquiring necessary information about highly qualified employees or potential customers. Industry experience also increases the credibility of the founder and, thus, his/her access to credit. Therefore, an entrepreneur's cultural capital of this sort may act as a buffer against the liabilities of newness and should be viewed as a crucial asset in the early phase of venture existence, when its development is primarily built around the entrepreneur (Cooper et al. 1994). We also expect that the impact of industry experience on the performance of the new venture is stronger in transition economies than in mature ones. Transition economies are still characterized by resource scarcity and a weaker institutional framework of entrepreneurship (Smallbone/Welter 2001), which results in a higher importance of social contacts for economic actions. Founders in transition economies who possess a broader network of industry contacts therefore have better chances to mobilize the scarce financial and human resources crucial to the venture, which are more difficult to achieve than for founders in mature economies. As result, we hypothesize that:

H4: There will be a positive correlation between the industry experience of the entrepreneur and enterprise performance.

H4a: The relationship between the industry experience of the entrepreneur and enterprise performance in (less advanced) transition economies will be stronger than that of their counterparts in mature economies.

In addition to the direct effects, we also expect that the industry experience of the entrepreneur has an indirect impact on new venture performance via entrepreneurial skills. Entrepreneurial skills can be viewed as the founder's ability to recognize and take advantage of new business opportunities (Chandler/Hanks 1998). We assume that possessing industry-related knowledge in the pre-startup phase facilitates the recognition of high-quality business opportunities. Further, founders who possess industry experience have developed capabilities specific to a particular market that enable them to adjust their venture-related decisions to the market's requirements, thus enabling them to better exploit new business ideas. We also expect that the effect of industry experience on entrepreneurial skills is stronger in transition economies than in mature ones. In contrast to mature economies, founders in post-communism countries until the mid 1990s had very limited possibilities in schools, universities or the family to learn how to seize and exploit new business opportunities. Therefore, industry experience may still be crucial to developing such capabilities in the transition context. As a result, we hypothesize that:

H5: There will be a positive correlation between the industry experience and the entrepreneurial skills of the entrepreneur.

H5a: The relationship between industry experience and the entrepreneurial skills of entrepreneurs in (less advanced) transition economies will be stronger than that of their counterparts in mature economies. 


\section{Entrepreneurial skills}

Following cultural capital theory, we can assume that the higher the founder's investments in entrepreneurial abilities, the better will be his/her decisions and actions regarding the new venture, and the better will be the firm's performance (Bourdieu 1986). Especially in the early phases of the venture, the ability to recognize and take advantage of new business opportunities has to be viewed as the core of entrepreneurship (Timmons 2002). The quality of the entrepreneurial process determines the dynamic of the venture's development and the level of organizational outcomes (Garnsey 1998). Entrepreneurs who choose promising business ideas, formulate adequate strategy for taking advantage of the opportunity, and acquire and use resources to implement the firm's strategy efficiently are therefore expected to perform better than their counterparts (Chandler/Hanks 1994, 1998). Moreover, we assume that the founder's ability to recognize and exploit these new opportunities plays a more relevant role in entrepreneurial outcomes in unstable environments which lack abundant resources: "Disequilibrium and uncertainty create an increased need for entrepreneurial skills" (Orazem/Vodopivec 1997: 896). Because the environment facing entrepreneurs in transition economies is still less stable and more resource-constrained, their entrepreneurial abilities are crucial in coping with dynamic changes, instability and low market transparency. We hypothesize that:

H6: There will be a positive correlation between the entrepreneurial skills of the founder and enterprise performance.

H6a: The relationship between the entrepreneurial skills of the founders and enterprise performance in (less advanced) transition economies will be stronger than that of their counterparts in mature economies.

\section{Individualistic values}

In an entrepreneurial context, people displaying a high degree of individualism are expected to perform better than those that do not. Individualism is associated with such values as competition, enjoyment, pleasure, an exciting and varied life, self-reliance, social recognition, imagination and broad-mindedness (Morris/Schindehutte 2005). Individuals possessing such value-based profiles show a higher proclivity to create new ventures, to innovate and to be oriented toward material goals: "Individualism gives rise to entrepreneurial behavior and a greater supply of individualism leads to greater levels of entrepreneurial outcomes" (Tiessen 1997: 372). In countries where values relevant to economic innovation and personal success may conflict with traditional cultural values, entrepreneurship may not be approved of by society (Morris/Schindehutte 2005) and the hostile environment may hamper entrepreneurial outcomes. Individualistic values such as personal initiative, innovativeness and entrepreneurship were not cultivated in communism; but as Lee and Peterson 
(2000) state, such values are now encouraged in countries in transition toward a free-market economy. We argue that entrepreneurs who are more independent, creative, risk-taking and enjoyment-seeking are therefore better "equipped" to act competitively in economies in transition toward the free market. As result, we hypothesize that:

H7: There will be a positive correlation between the individualistic values of the entrepreneur and enterprise performance.

H7a: The relationship between the individualistic values of entrepreneurs and enterprise performance in (less advanced) transition economies will be stronger than in mature economies.

We also expect that the individualistic values of the entrepreneur have an indirect influence on new venture performance via entrepreneurial skills. Because individualistic-oriented persons strive to be independent and to have a challenging life, they can be expected to have a higher ability to recognize new business opportunities and a stronger desire to start a venture (Mitchell et al. 2000). Moreover, people expressing individualistic values are also likely to be more creative, autonomous and achievement-oriented. Those individualistic values may be reflected in performance-oriented entrepreneurial behavior (for example, seizing innovative ideas, optimizing organizational resources, and motivating employees through achievement-oriented incentives). Tiessen (1997) argues that individualism plays an important role in generating the variety of organizational resources. Hence, it may be assumed that founders who reflect strong individualistic values have a greater ability than others to exploit new business opportunities. We do not expect significant differences in the impact of individualism on the ability to recognize and utilize new business opportunities to exist between the transition economies and the more advanced European countries. We hypothesize that:

H8: There will be a positive correlation between individualistic values and entrepreneurial skills of the entrepreneur.

H8a: There will be no significant country differences in the strength of the relationship between individualistic values and entrepreneurial skill of the entrepreneur.

Finally, we assume that individualism positively affects the entrepreneur's satisfaction with being self-employed. Following Brown's theoretical framework of value-based occupational choice, satisfaction and success (2002), the main reason for job satisfaction for people with an individualistic profile is the congruence between the values reinforced on the job and those held by the individual. Thus, if the career choice of an individualistic person satisfies values he/she holds, the satisfaction of that occupational option will be higher. As entrepreneurship is associated strongly with independence, innovativeness, autonomy and risk-taking (Stevenson 1999), we can assume that founders 
possessing individualistic values are more satisfied with self-employment as a career, irrespective of their country. We hypothesize that:

H9: There will be a positive correlation between individualistic values and an individual's satisfaction with being an entrepreneur.

H9a: There will be no national differences in the strength of the relationship between individualistic values and an individual's satisfaction of being an entrepreneur.

\section{New venture performance}

In our research, we regard organizational success and founder's satisfaction of being an entrepreneur as key interrelated performance dimensions. Especially in the early stage of a firm, the entrepreneur and his/her business venture can usually be viewed as a single unit. Entrepreneur's satisfaction may therefore be treated as a kind of motivational capital for the further development of the new venture (Kirkman/Shapiro 2001). We expect that organizational performance will strongly affect entrepreneur's satisfaction with being self-employed. Namely, founders who achieve favourable results, such as securing financial liquidity and increase in organizational resources and sales, are more likely to be comfortable with their career choice of self-employment than those who do not. In addition to that, we expect that organizational outcomes have a stronger impact on the founder's satisfaction of being self-employed in transition economies than in mature economies. Necessity entrepreneurship is relatively more common in transition economies than in high income countries (Bosma/Harding 2007). Therefore, we can expect that a desirable development of the organization will increase their wish to remain as an entrepreneur. We hypothesize that:

H10: There will be a positive correlation between enterprise performance and an individual's satisfaction of being an entrepreneur.

H10a: The relationship between enterprise performance and an individual's satisfaction of being an entrepreneur will be stronger in (less advanced) transition economies than in mature economies.

\section{Methodology}

As a basis for this study, we designed a standardized questionnaire for a written survey. The first draft underwent pre-testing in Austria, Poland and Slovenia, resulting in a reduction of questions and a simplification of its wording. After the translation process, the final questionnaire was tested again among randomly selected business founders.

\section{Sample}

The population consists of new enterprises in Austria, Poland and Slovenia that were created on average six months before the survey. 
The randomly sampled sets of data with new ventures were provided by those national agencies, where new ventures are registered. Specifically, in Austria, the database was provided by the Chamber of Commerce. In Poland, the National Statistical Office supplied the contact data for new enterprises. In Slovenia, the database was provided by the Agency of the Republic of Slovenia for Public Legal Records and Related Services. ${ }^{5}$

The new ventures in all three investigated countries were contacted in January 2007. In Austria 211 completed questionnaires (11.6 percent) were returned. The data cleaning process resulted in a sample of 170 start-ups. In Poland, we received 196 questionnaires (6.1 percent), resulting in 167 usable cases. ${ }^{6}$ And finally, in Slovenia, 397 questionnaires (12.4 percent) were returned, resulting in 352 for further analysis.

5 Due to the long information accumulation process, the national agencies could not provide us with the needed data until on average 3-6 months after the firm registration. Thus, we shall recognize some survival bias in our sample. With our design, however, we overcome the retrospective method of analysis, which usually suffers from the information bias. It is still unique in entrepreneurship research to accompany the founder close to the business start-up moment.

6 We are aware of the low response rate in Poland. But our intention is not to formulate any generalizations of the findings, but rather to show a trend pertaining to the effects of cultural capital on new venture performance in different environments. In addition to that, it has to be stressed that Poland - probably due to the deeper communist legacy than in the former Yugoslavia - still belongs to the Europeans countries with one of the lowest level of trust to others and to the state. The low response rate can reflect it. 


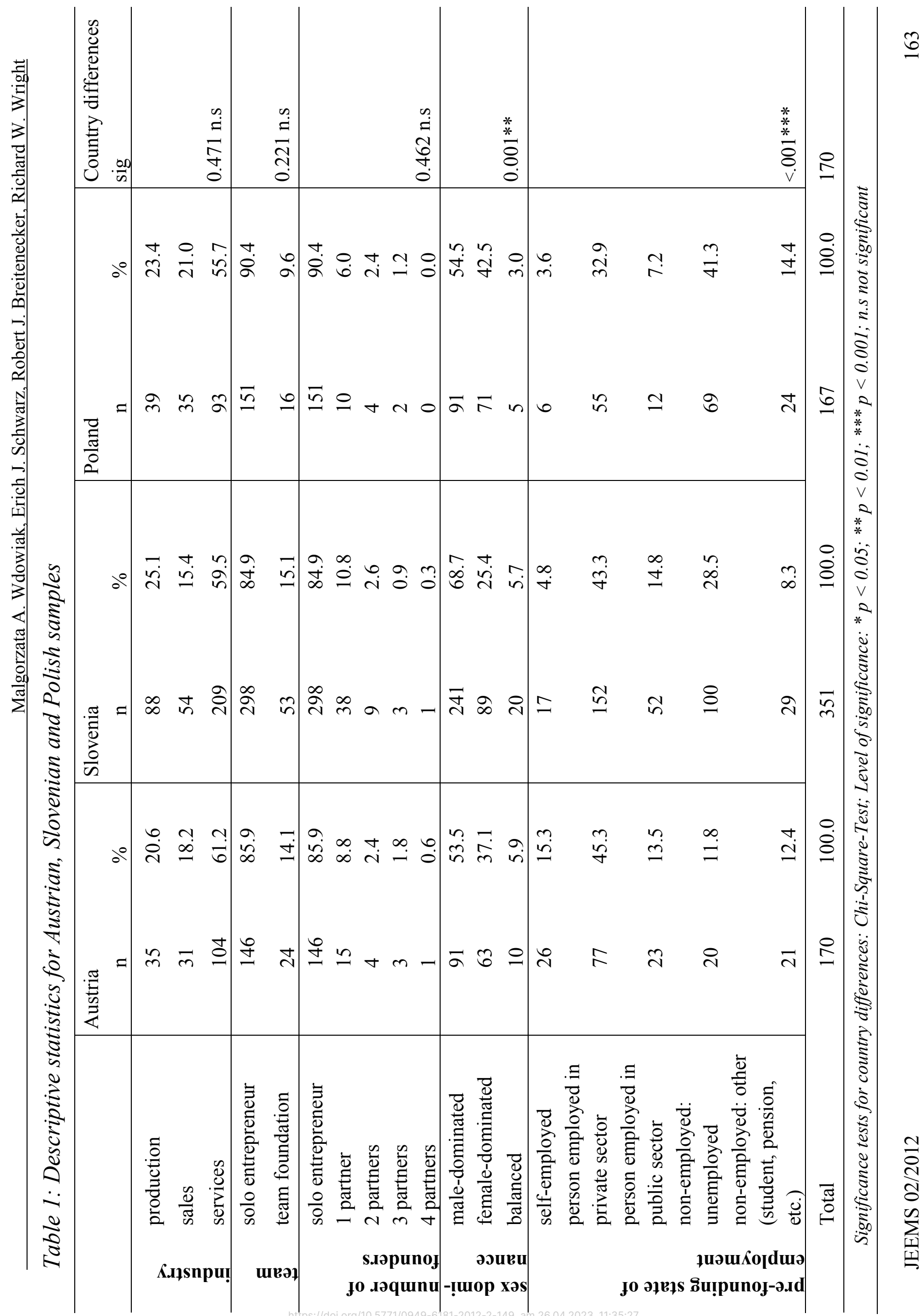




\section{Sample descriptive}

At the business level, our descriptive statistics show no significant differences among Austrian, Polish and Slovenian start-ups concerning industry sector, team vs. solo foundations, and the number of founders (Table 1).

However, on the personal level, we note several significant differences. Founders in Slovenia and Poland are on average three years younger than those in Austria. The mean age of the founders (or of a founding team) in Austria is 39.8 years, whereas the mean age in Slovenia and Poland is 36.6 and 36.4 years respectively.

The gender of entrepreneurs is expressed as that of the founder in the case of a solo foundation; in team foundations the gender can be male-dominated, femaledominated, or balanced. Significant differences are seen in the results for the three countries. Considerably fewer enterprises were founded by women in Slovenia (25.4 percent) than in Austria (37.1 percent) or in Poland, where 42.5 percent of the start-ups were female-dominated.

Differences among the three countries are also seen in the pre-founding state of employment, with more entrepreneurs starting their business from selfemployment in Austria (15.3 percent) than in Slovenia (4.8 percent) or in Poland (3.6 percent). A higher percentage of Polish entrepreneurs (55.7 percent) were unemployed before starting their businesses, compared to 36.8 percent in Slovenia and only 24.2 percent in Austria.

Findings about the pre-founding state of employment are consistent with results of the motives for establishing a business. In all three countries, entrepreneurs create new ventures largely in recognition of a business opportunity (Table 2). In Austria and Slovenia the wish to realize one's own business idea is the paramount reason for founding a new venture. Polish and Slovenian entrepreneurs are more likely than Austrians to start new businesses because they were unemployed or needed to ensure the survival of their family. 


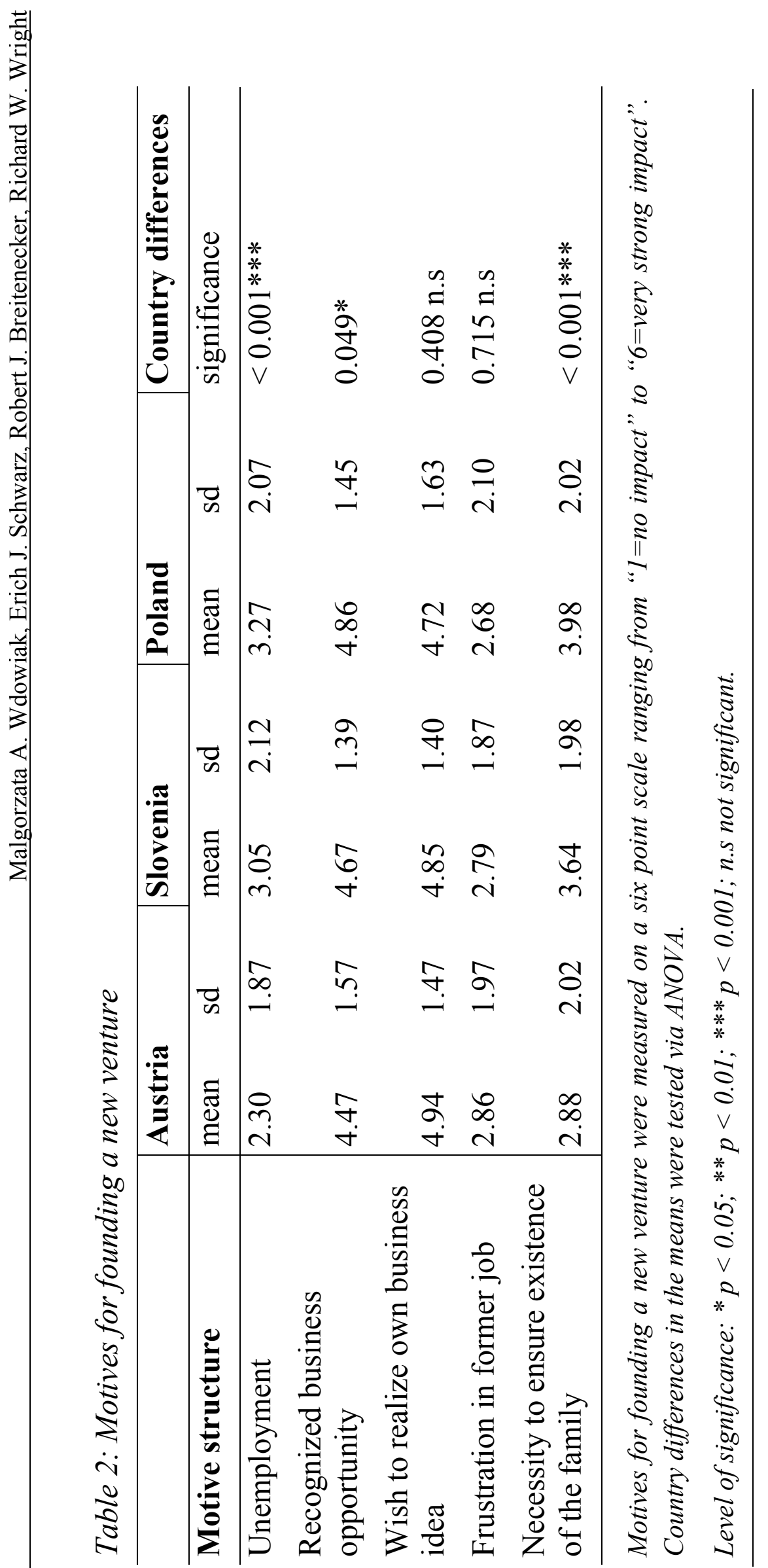




\section{Method}

The causal relationships between constructs were analyzed through structural equation modelling using the Partial Least Squares (PLS) approach. PLS was chosen for several reasons. Normal distribution cannot be assumed for all items (such as education), and the PLS approach does not require distributional assumptions. Moreover, sample sizes for Austria and Poland are less than the required size of 200 for covariance-based structural equation modeling using the Maximum Likelihood approach. Estimation of the structures path model was done using the free software environment SmartPLS (Hansmann 2004).

In entrepreneurship research, various measures of new venture performance, such as profit increase or growth in employment, have been applied (Weinzimmer/Nystrom/Freeman 1998; Murphy/Trailer/Hill 1996). However, these measures relate mostly to mature enterprises in later stages of organizational emergence. We would not expect to see new ventures reaching their break-even points or hiring new employees only a few months into their existence. So, objective performance indicators are hardly applicable in the context of the very young firms. For this reason, we use subjective measures of new venture performance that refer to the entrepreneur's evaluation of the hitherto development of his/her new firm. Specifically, we apply two interrelated performance dimensions: enterprise performance (early organizational performance) and founder's satisfaction of being an entrepreneur. We define enterprise performance as the degree of founder's satisfaction with the attainment of diverse business goals, like number of customers, market share compared to competitors, reputation among customers, and development of sales. These indicators reflect the conversion of individual capital into organizational capital. Customer base and firm legitimacy constitute social capital of young organizations. Market share and sales form economic capital of new ventures. Founder's satisfaction of being an entrepreneur reflects his/her emotional evaluation of this career choice. Entrepreneur's satisfaction is a kind of motivational capital of the new organization that is usually built around the entrepreneur. As mentioned, previous studies agree with the assumption that entrepreneur's behavior and decisions in subsequent stages of firm development are determined not only by hitherto realized organizational outcomes, but also by founder's satisfaction of being self-employed (Kirkman/Shapiro 2001).

There are also many approaches to measuring cultural values (Ritchie/Brindley 2005; Lee and Peterson 2000). We adapted scales from the Short Schwartz's Value Survey that refer to individualism, such as hedonism, stimulation and self-direction (Schwartz 1992; Lindeman/Verkasalo 2005). Schwartz's valuebased approach has been successfully validated in many countries with varied cultural features. With respect to entrepreneurial skills, we followed measures developed and validated by Chandler and Hanks (1998), which focus on the 
individual's ability to recognize and to take advantage of a new business opportunity. The measurement of endogenous and exogenous variables used in the study is presented in Table 3 .

Table 3: Measurement of the constructs of the study

\begin{tabular}{|c|c|c|c|}
\hline & $\begin{array}{l}\text { Label (number } \\
\text { of items) }\end{array}$ & Description & Source \\
\hline \multirow{7}{*}{$\begin{array}{l}\text { Early new } \\
\text { venture } \\
\text { performance }\end{array}$} & \multirow{4}{*}{$\begin{array}{l}\text { enterprise } \\
\text { perfor-mance } \\
\text { (4) }\end{array}$} & EP1 - reputation among customers & \multirow{4}{*}{$\begin{array}{l}\text { self- } \\
\text { developed }\end{array}$} \\
\hline & & $\begin{array}{l}\text { EP2 - market share compared to } \\
\text { competitors }\end{array}$ & \\
\hline & & EP3 - number of customers & \\
\hline & & EP4 - development of sales & \\
\hline & \multirow{3}{*}{$\begin{array}{l}\text { Entrepre-neur's } \\
\text { satisfaction (3) }\end{array}$} & $\begin{array}{l}\text { ES1 - happy about decision to become } \\
\text { an entrepreneur }\end{array}$ & \multirow{3}{*}{$\begin{array}{l}\text { following } \\
\text { Klandt } 1984\end{array}$} \\
\hline & & ES2 - higher life satisfaction & \\
\hline & & ES3 - wish to remain entrepreneur & \\
\hline $\begin{array}{l}\text { Institutional-ized } \\
\text { cultural capital }\end{array}$ & education & ED1 - degree of education & \\
\hline \multirow{8}{*}{$\begin{array}{l}\text { Incorporated } \\
\text { cultural capital }\end{array}$} & \multirow{4}{*}{$\begin{array}{l}\text { Entrepre- } \\
\text { neurial skills } \\
\text { (4) }\end{array}$} & MS1 - influence and lead people & \multirow{4}{*}{$\begin{array}{l}\text { following } \\
\text { Chandler/ } \\
\text { Hanks } 1998\end{array}$} \\
\hline & & $\begin{array}{l}\text { MS2 - seize high quality business } \\
\text { opportunities }\end{array}$ & \\
\hline & & $\begin{array}{l}\text { MS3 - achieve results by organizing } \\
\text { resources and } \\
\text { motivating people }\end{array}$ & \\
\hline & & MS4 - delegate effectively & \\
\hline & \multirow{3}{*}{$\begin{array}{l}\text { individualistic } \\
\text { values (3) }\end{array}$} & $\begin{array}{l}\text { IV1 - hedonism (enjoyment in life and } \\
\text { pleasure seeking) }\end{array}$ & \multirow{3}{*}{$\begin{array}{l}\text { following } \\
\text { Schwartz } \\
1992 ; \\
\text { Lindeman/ } \\
\text { Verkasalo } \\
2005\end{array}$} \\
\hline & & $\begin{array}{l}\text { IV2 - stimulation (daring, exciting and } \\
\text { very } \\
\text { challenging life) }\end{array}$ & \\
\hline & & $\begin{array}{l}\text { IV3 - self-direction (creativity, } \\
\text { independence, and choosing own } \\
\text { goals) }\end{array}$ & \\
\hline & $\begin{array}{l}\text { industry } \\
\text { experience }\end{array}$ & IE1 - years of industry experience & \\
\hline
\end{tabular}

All items were measured on a 6-point ordinal scale, except education, which was measured on a 4-point ordinal scale. 


\section{Results and discussion}

\section{Measurement model}

The measurement models perform adequately for all three countries (Table 4). All item loadings for reflective constructs are over the recommended parameter value of 0.7 , except item IV1 for individualistic values in the model for Poland, which has a loading of 0.633 . Thus, individual indicator reliability can be assumed (Krafft 2005: 73). All loadings are significant to the 1\% level running 500 bootstrap samples.

Construct reliability was tested using the composite reliability measure (CR). The indices for CR are between 0.802 and 0.913 . All CR values lie over the recommended threshold of 0.7 ; and thus, construct reliability can be assumed.

Discriminant validity implies that measures from a given construct differ from measures of other constructs (Hulland 1999). We used the average variance extracted (AVE) to examine discriminant validity. The values for AVE are between 0.573 and 0.778 and lie above the recommended threshold of 0.5 (Krafft 2005: 74). According to Fornell (1981: 46), the square-roots of AVE values should be greater than the values in the appropriate rows and columns of correlation matrix of latent variables to obtain discriminant validity. Tables 5 to 7 show the correlation matrix for latent constructs for each of the three country models. In the diagonal, the square root of the average variance extracted is printed in bold. The criteria of Fornell and Larcker are fulfilled. Further, cross loadings show that all items have the highest loadings on their respective construct and every construct loads highest with its own items. Thus discriminant validity can be assumed (Hulland 1999; Krafft 2005). 


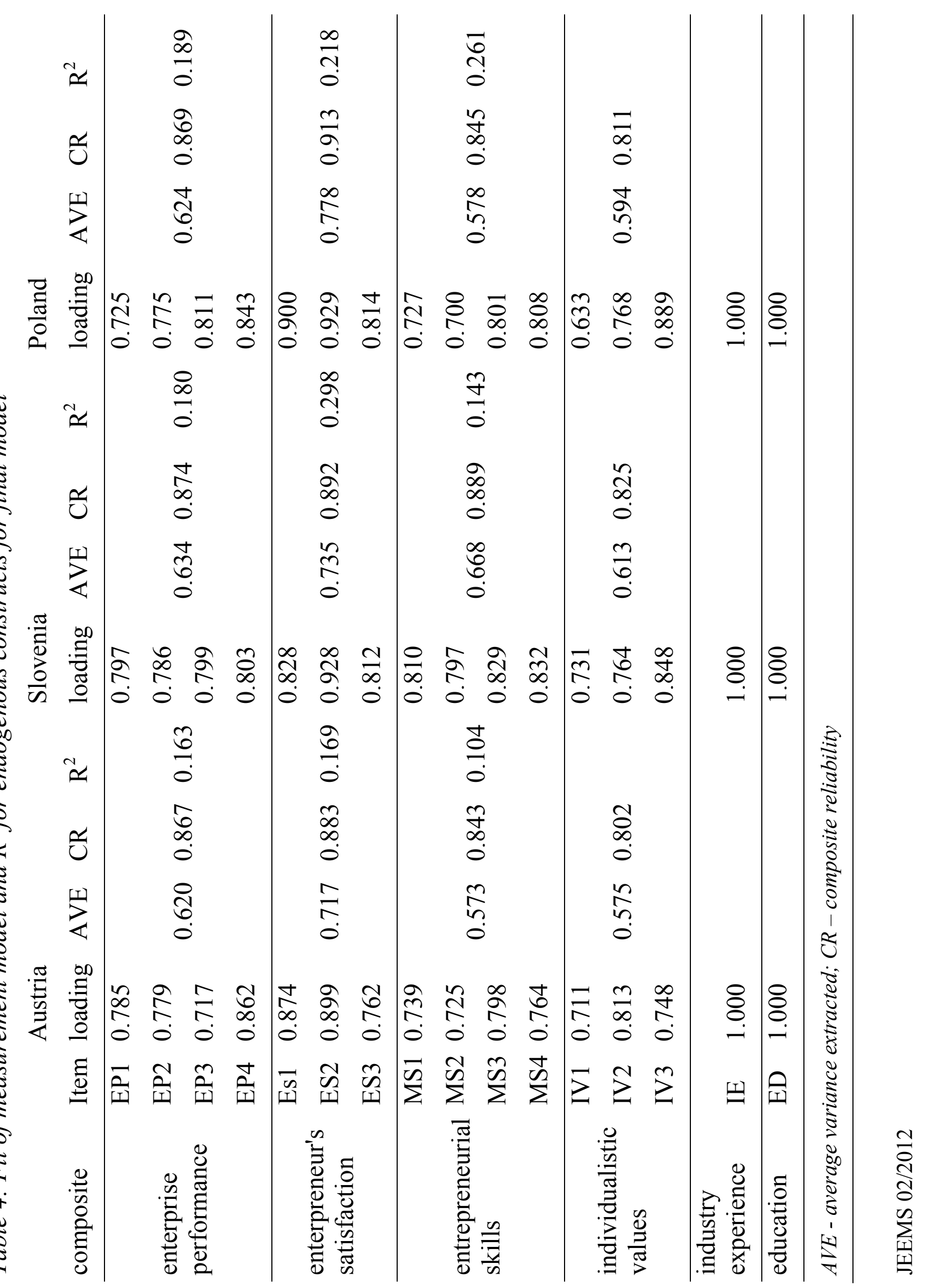


Table 5: Correlation matrix of the latent constructs with root of AVE in the diagonal (Austria)

\begin{tabular}{lllllll}
\hline Austria & $(1)$ & $(2)$ & $(3)$ & $(4)$ & $(5)$ & $(6)$ \\
\hline $\begin{array}{l}\text { (1) education } \\
\begin{array}{l}\text { (2) enterpreneur's } \\
\text { satisfaction }\end{array}\end{array}$ & formative & & & & & \\
$\begin{array}{l}\text { (3) enterprise } \\
\text { performance }\end{array}$ & -0.022 & $\mathbf{0 . 8 4 7}$ & & & & \\
$\begin{array}{l}\text { (4) entrepreneurial } \\
\text { skills }\end{array}$ & -0.154 & 0.281 & $\mathbf{0 . 7 8 7}$ & & & \\
$\begin{array}{l}\text { (5) individualistic } \\
\text { values }\end{array}$ & 0.000 & 0.329 & 0.115 & 0.312 & $\mathbf{0 . 7 5 8}$ & \\
$\begin{array}{l}\text { (6) industry } \\
\text { experience }\end{array}$ & -0.014 & -0.018 & 0.128 & 0.039 & -0.124 & formative \\
\hline
\end{tabular}

Table 6: Correlation matrix of the latent constructs with root of AVE in the diagonal (Slovenia)

\begin{tabular}{lllllll}
\hline \multicolumn{1}{c}{ Slovenia } & $(1)$ & $(2)$ & $(3)$ & $(4)$ & $(5)$ & $(6)$ \\
\hline $\begin{array}{l}\text { (1) education } \\
\begin{array}{l}\text { (2) entrepreneur's } \\
\text { satisfaction }\end{array}\end{array}$ & -0.063 & $\mathbf{0 . 8 5 7}$ & & & & \\
$\begin{array}{l}\text { (3) enterprise } \\
\text { performance }\end{array}$ & -0.011 & 0.440 & $\mathbf{0 . 7 9 6}$ & & & \\
$\begin{array}{l}\text { (4) intrepreneu- } \\
\text { rial skills }\end{array}$ & 0.008 & 0.334 & 0.399 & $\mathbf{0 . 8 1 7}$ & & \\
$\begin{array}{l}\text { (5) individualistic } \\
\text { values }\end{array}$ & -0.128 & 0.390 & 0.161 & 0.337 & $\mathbf{0 . 7 8 3}$ & \\
$\begin{array}{l}\text { (6) industry } \\
\text { experience }\end{array}$ & 0.047 & 0.058 & 0.190 & 0.142 & -0.074 & formative \\
\hline
\end{tabular}


Table 7: Correlation matrix of the latent constructs with root of AVE in the diagonal (Poland)

\begin{tabular}{lllllll}
\hline Slovenia & $(1)$ & $(2)$ & $(3)$ & $(4)$ & $(5)$ & $(6)$ \\
\hline $\begin{array}{l}\text { (1) education } \\
\begin{array}{l}\text { (2) entrepreneur's } \\
\text { satisfaction }\end{array}\end{array}$ & -0.021 & $\mathbf{0 . 8 8 2}$ & & & & \\
$\begin{array}{l}\text { (3) enterprise } \\
\text { performance }\end{array}$ & -0.019 & 0.458 & $\mathbf{0 . 7 9 0}$ & & & \\
$\begin{array}{l}\text { (4) entrepreneu- } \\
\text { rial skills }\end{array}$ & 0.104 & 0.267 & 0.404 & $\mathbf{0 . 7 6 0}$ & & \\
$\begin{array}{l}\text { (5) individualistic } \\
\text { values }\end{array}$ & 0.121 & 0.232 & 0.319 & 0.500 & $\mathbf{0 . 7 7 0}$ & \\
$\begin{array}{l}\text { (6) industry } \\
\text { experience }\end{array}$ & 0.031 & -0.025 & 0.010 & -0.106 & -0.026 & formative \\
\hline
\end{tabular}

\section{Structural model}

The $\mathrm{R}^{2}$ measures for the latent endogenous constructs are between 0.104 and 0.169 in the Austrian model, from 0.143 to 0.298 in the Slovenian, and from 0.189 to 0.261 in the Polish model (Table 4). Significance of path models was tested running 500 bootstrap samples. In the Austrian model, six of ten path coefficients are significant, one only to a confidence level of $10 \%$. In the Slovenian model, six of ten path coefficients are significant. In the Polish model, four out of ten path coefficients are significant, one at the $10 \%$ level.

The findings support three out of ten hypotheses (H6, H8, H10) for all three of the country models. One hypothesis (H7) can be accepted only for Poland and one (H5) only for Slovenia. Two hypotheses (H4, H9) can be accepted only for the Austrian and Slovenian models. Figures 2 to 4 show the results for model estimation of the country samples. 
Figure 2: Structural model for Austria

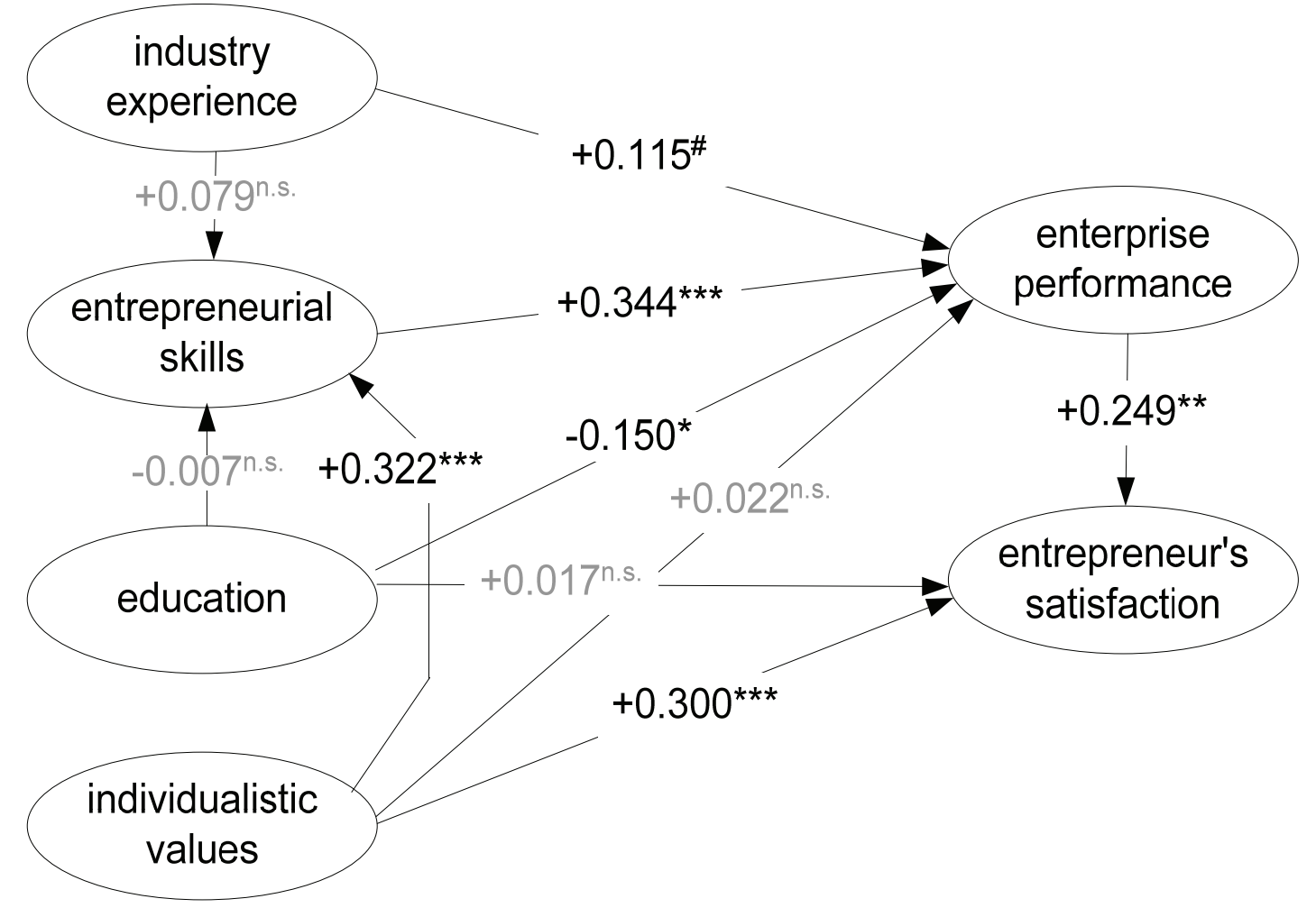

Level of significance: $* * * p<0.001 ; * * p<0.01 ; * p<0.05$; \#p $<0.1$; n.s not significant

Figure 3: Structural model for Slovenia

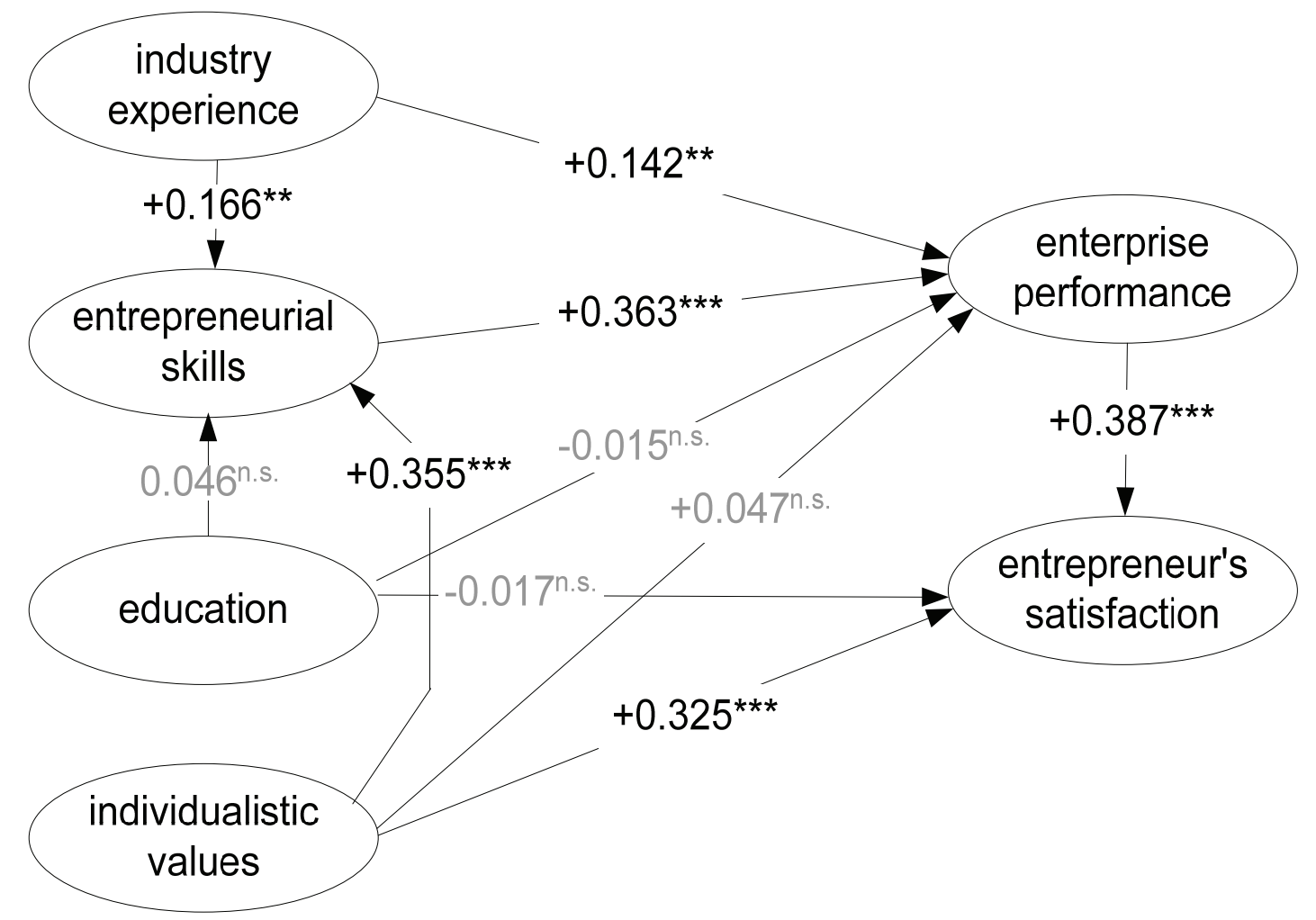

Level of significance: ${ }^{* * *} p<0.001 ; * * p<0.01 ; * p<0.05$; $p<0.1$; n.s not significant 
Figure 4: Structural model for Poland

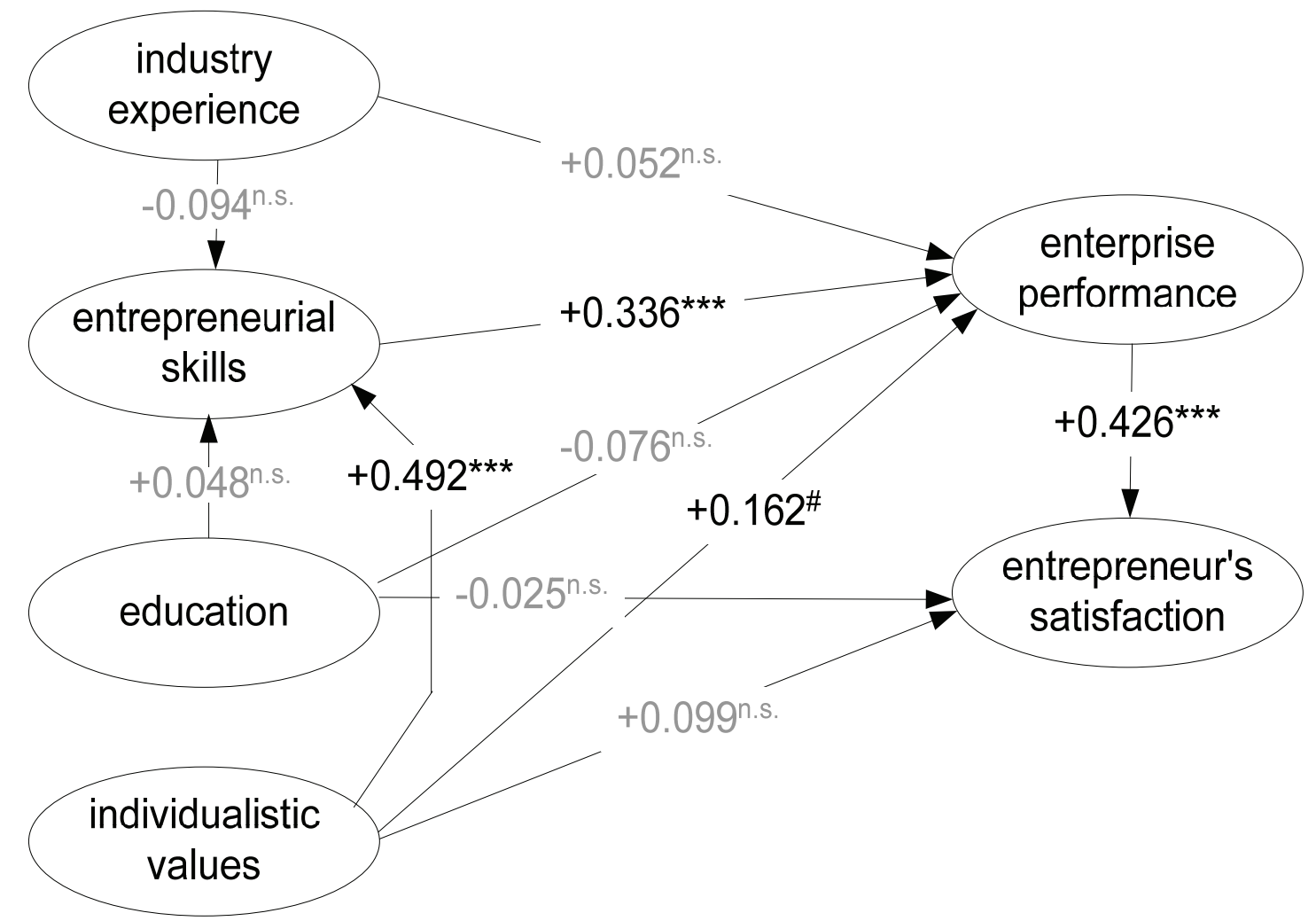

Level of significance: ${ }^{* * *} p<0.001 ;{ }^{* *} p<0.01 ; * p<0.05$; $\# p<0.1$; n.s not significant

Surprisingly, the path coefficient from educational level to enterprise performance is significantly negative in the Austrian model, the opposite of what we had expected. This deviation may be due to the fact that well-educated entrepreneurs often start their businesses in the high-tech sector, which is characterised by a longer and more capital-intensive period of product development. Hence, return on those investments cannot be expected in the early months of the venture's existence. The negative relationship between educational level and enterprise outcomes may also result, to some extent, from characteristics of the labor market: wage-employment as a career option is very desirable among Austrian graduates and wage-based career opportunities are high. Moreover, this effect may be connected with the subjective measurement of organizational performance (that is, the extent to which the entrepreneur is satisfied with diverse organizational outcomes such as the development of sales or reputation among customers). Well-educated founders are more likely to expect a higher return on their entrepreneurial investment and may therefore be less content with the early organizational development. In the Slovenian and Polish models, this path is not significant, which leads to the rejection of $\mathrm{H} 1$ for all three countries. Education shows no significant correlation with entrepreneurial skills and entrepreneurs' satisfaction in all three models. Therefore, $\mathrm{H} 2$ and $\mathrm{H} 3$ must also be rejected. The results indicate that education 
in all three countries does not yet foster the ability to recognize and exploit new business opportunities.

The path coefficient from industry experience to enterprise performance shows a significantly positive influence as expected in the models for Austria and Slovenia, but it is not significant in the one for Poland. So, H4 can be accepted only for Austria and Slovenia. The results may indicate that founders in lessadvanced transition economies still face a less stable and more dynamic environment that impedes the application of market knowledge acquired from previous industry experience. The parameter estimate from industry experience to entrepreneurial skills is positive only in the Slovenian model. Therefore, H5 can be accepted only for Slovenia.

The impact of entrepreneurial skills on enterprise performance is positive for Austria, Slovenia and Poland, thus supporting H6 in all three countries.

The expected positive influence of individualistic values on enterprise performance is substantiated in the model for Poland, but not for Austria or Slovenia; thus $\mathrm{H} 7$ can be accepted only for Poland. The findings indicate that in less advanced transition economies, where the founder has to function in a resource-constrained and often unstable institutional environment, the individualistic profile of the entrepreneur is one of the most crucial factors influencing new venture performance compared to education or industry experience. It strongly supports Bourdieu's assumption that economic analyses of people's actions have to be extended to encompass cultural values as well. Individualistic values show significantly positive correlations with entrepreneurial skills as expected for all three country models, supporting H8. The expected positive relationship between individualistic values and entrepreneur's satisfaction (H9) is supported in the Austrian and Slovenian samples, but not in the Polish model.

Finally, H10 can be accepted. The path coefficient from enterprise performance to entrepreneur's satisfaction is significantly positive in all three models.

\section{Group comparisons}

We employed a permutation test to examine the significance of groupdifferences in path coefficients among each pair of countries. The pathdifferences were tested running 1,000 permutation samples for each model comparison (\{Dibbern, $2005 \# 6190\}$ 147). The results are presented in Table 8. The $p$-value indicates the percentage of how many sampled path differences are greater or less than the observed path difference (one-sided test). 
Table 8: Model results including group comparisons

\begin{tabular}{|c|c|c|c|c|c|c|}
\hline & $\begin{array}{l}\text { Slovenia } \\
(\mathrm{n}=351)\end{array}$ & $\begin{array}{l}\text { Poland } \\
(\mathrm{n}=167)\end{array}$ & $\begin{array}{l}\text { Austria } \\
(\mathrm{n}=170)\end{array}$ & $\begin{array}{l}\text { Country } \\
\text { Difference }\end{array}$ & & \\
\hline & $\begin{array}{l}\text { path } \\
\text { (t-value) }\end{array}$ & $\begin{array}{l}\text { path } \\
\text { (t-value) }\end{array}$ & $\begin{array}{l}\text { path } \\
\text { (t-value) }\end{array}$ & $\begin{array}{l}\text { Austria- } \\
\text { Slovenia } \\
\text { p-value }\end{array}$ & $\begin{array}{l}\text { Austria- } \\
\text { Poland } \\
\text { p-value }\end{array}$ & $\begin{array}{l}\text { Poland- } \\
\text { Slovenia } \\
\text { p-value }\end{array}$ \\
\hline education & $-0,017$ n.s & $-0,025 \mathrm{n} . \mathrm{s}$ & $0,017 \mathrm{n} . \mathrm{s}$ & $-0,034$ n.s & $-0,041 \mathrm{ln} . \mathrm{s}$ & $-0,008 \mathrm{n} . \mathrm{s}$ \\
\hline $\begin{array}{l}\text {->enterpreneur's } \\
\text { satisfaction }\end{array}$ & $(0,349)$ & $(0,387)$ & $(0,229)$ & $41,5 \%$ & $32,6 \%$ & $45,6 \%$ \\
\hline education & $-0,015$ n.s & $-0,076$ n.s & $-0,150 *$ & 0,136 n.s & 0,075 n.s & $-0,061$ n.s \\
\hline $\begin{array}{l}\text {->enterprise } \\
\text { performance }\end{array}$ & $(0,297)$ & $(1,006)$ & $(2,097)$ & $12,8 \%$ & $21,3 \%$ & $24,0 \%$ \\
\hline education & 0,046 n.s & 0,048 n.s & $-0,007$ n.s & $0,053 \mathrm{n} . \mathrm{s}$ & $0,054 \mathrm{n} . \mathrm{s}$ & $0,002 \mathrm{n} . \mathrm{s}$ \\
\hline $\begin{array}{l}\text {->entrepreneurial } \\
\text { skills }\end{array}$ & $(0,868)$ & $(0,661)$ & $(0,077)$ & $33,2 \%$ & $28,9 \%$ & $49,4 \%$ \\
\hline $\begin{array}{l}\text { enterprise } \\
\text { performance }\end{array}$ & $0,387 * * *$ & $0,426 * * *$ & $0,249 * *$ & $0,138 \#$ & $0,176 \#$ & 0,039 n.s \\
\hline $\begin{array}{l}\text {->enterpreneur's } \\
\text { satisfaction }\end{array}$ & $(9,455)$ & $(5,397)$ & $(3,095)$ & $8,7 \%$ & $6,7 \%$ & $36,7 \%$ \\
\hline entrepreneurial skills & & & & & $-0,008$ & \\
\hline $\begin{array}{l}\text {->enterprise } \\
\text { performance }\end{array}$ & $\begin{array}{l}0,363 * * * \\
(6,962)\end{array}$ & $\begin{array}{l}0,336 * * * \\
(4,191)\end{array}$ & $\begin{array}{l}0,344 * * * \\
(4,603)\end{array}$ & $\begin{array}{l}0,019 \mathrm{n.s} \\
42,2 \%\end{array}$ & $\begin{array}{l}\text { n.s } \\
47,4 \%\end{array}$ & $\begin{array}{l}-0,027 \text { n.s } \\
37,3 \%\end{array}$ \\
\hline individualistic values & $0,325 * * *$ & 0,099 n.s & $0,300 * * *$ & $0,025 \mathrm{n} . \mathrm{s}$ & $-0,201 *$ & $-0,226 * *$ \\
\hline $\begin{array}{l}\text {->enterpreneur's } \\
\text { satisfaction }\end{array}$ & $(5,966)$ & $(1,134)$ & $(4,295)$ & $38,2 \%$ & $3,2 \%$ & $0,8 \%$ \\
\hline individualistic values & 0,047 n.s & $0,162 \#$ & $0,022 \mathrm{n.s}$ & $0,026 \mathrm{n} . \mathrm{s}$ & 0,140 n.s & 0,114 n.s \\
\hline $\begin{array}{l}\text {->enterprise } \\
\text { performance }\end{array}$ & $(0,901)$ & $(1,775)$ & $(0,257)$ & $44,2 \%$ & $10,3 \%$ & $11,2 \%$ \\
\hline individualistic values & $0,355 * * *$ & $0,492 * * *$ & $0,322 * * *$ & 0,033 n.s & $0,170 \#$ & 0,137 \# \\
\hline $\begin{array}{l}\text {->entrepreneurial } \\
\text { skills }\end{array}$ & $(6,994)$ & $(8,957)$ & $(4,102)$ & $40,8 \%$ & $5,5 \%$ & $9,1 \%$ \\
\hline $\begin{array}{l}\text { industry experience } \\
\text {->enterprise } \\
\text { performance }\end{array}$ & $\begin{array}{l}0,142 * * \\
(2,953)\end{array}$ & $\begin{array}{l}0,052 \mathrm{n} . \mathrm{s} \\
(0,692)\end{array}$ & $\begin{array}{l}0,115 \# \\
(1,658)\end{array}$ & $\begin{array}{l}0,027 \mathrm{n} . \mathrm{s} \\
39,9 \%\end{array}$ & $\begin{array}{l}-0,063 \\
\text { n.s } \\
24,7 \%\end{array}$ & $\begin{array}{l}-0,090 \mathrm{n} . \mathrm{s} \\
16,0 \%\end{array}$ \\
\hline $\begin{array}{l}\text { Industry experience } \\
\text {->entrepreneurial } \\
\text { skills }\end{array}$ & $0,166 * * *$ & $-0,094$ n.s & 0,079 n.s & 0,087 n.s & $-0,173 \#$ & $-0,260 * *$ \\
\hline
\end{tabular}

Level of significance: ${ }^{* * *} p<0.001 ;{ }^{* *} p<0.01 ; * p<0.05$; $\# p<0.1 ;$ n.s not significant 


\section{Differences between mature and transition economies}

Comparing the Austrian and Slovenian models, only one of seven hypothesized path-differences could be supported. The identified difference in path coefficient is enterprise performance to entrepreneur's satisfaction, which is significant at the $10 \%$ level. As expected, organizational performance has a stronger impact on the founder's satisfaction with being self-employed in transition economies, resulting largely from differences in the motivation for founding the business. Slovenian entrepreneurs identify unemployment and the necessity to ensure the survival of their families significantly more often than Austrians as a main reason for business creation. Other differences are not significant. This result confirms that the transition process of the Slovenian economy is already very advanced.

When comparing the Austrian and Polish models, two of the seven hypothesized path-differences could be confirmed. The relationship between enterprise performance and entrepreneur's satisfaction is stronger in Poland because of significantly more necessity-driven entrepreneurship (at the $10 \%$ level of significance). Unexpectedly, we found a difference in path coefficient between individualistic values and entrepreneur's satisfaction at the 5\% level of significance. Austria's more individualistic entrepreneurs feel greater satisfaction with their career choice of self-employment than do entrepreneurs in Poland. Next, we identified a difference in path coefficient between individualistic values and entrepreneurial skills, significant at the $10 \%$ level. In Poland, individualistic values have a significantly stronger impact on entrepreneurial skills than in Austria. Considering that education and industry experience in Poland are not significant influence factors in an entrepreneurial context, a more embodied capital, such as individualistic values, appears to be essential in developing abilities to identify and exploit new market opportunities in less stable and less transparent institutional environments. Finally, we found a difference in the path coefficient from industry experience to entrepreneurial skills at the $10 \%$ level of significance. However, the expected positive relationship (H5) was not found for either country model; and thus hypothesis $\mathrm{H} 5 \mathrm{a}$ must be rejected.

\section{Differences between transition economies}

We also consider heterogeneity among transition countries that are at different stages of economic development and democratization. In our study, Slovenia represents advanced transition economies and Poland embodies middleadvanced transition economies. We discovered three significant differences between the two countries. In Slovenia, significantly more individualistic entrepreneurs are satisfied that they are self-employed (at the 1\% level of significance). Considering similar results of the comparison of the Austrian and Polish models, we may conclude that occupational satisfaction of Polish 
entrepreneurs may be strongly influenced by other factors, such as the extent to which their career choice is approved by their family and friends. It would indicate that Polish founders retain a more collective profile than do entrepreneurs in more advanced market economies (Brown 2002). ${ }^{7}$ As in the comparison of the Austrian and Polish models, we found that the individualistic values of Polish entrepreneurs have a significantly stronger effect on entrepreneurial skills than those of Slovenian entrepreneurs (at the 10\% level of significance). It confirms the assumption that in resource-constrained and less stable institutional environments, individualistic values are more crucial for developing a capacity to take advantage of new business opportunities. Finally, in contrast to the Polish founders, the industry experience of Slovenian entrepreneurs does contribute to the development of entrepreneurial skills.

\section{Conclusions and implications for future research}

In this study, we investigated the factors contributing to the early performance of new ventures in transition and mature economies. We have adapted models from sociology to the field of entrepreneurship. Specifically, we applied the cultural-capital-based approach of Bourdieu who argues that the behaviour of individuals and their outcomes depend not only on education and job training as human-capital theoreticians believe, but also upon abilities, cultural values or routines developed early in a person's life.

We found that the cultural capital of the entrepreneur strongly determines the early performance of new ventures, irrespective of the country context. In particular, industry experience and entrepreneurial skills have a positive impact on enterprise performance. Further, entrepreneurial skills are influenced strongly by the individualistic values of the founder. Individualistic values also positively affect entrepreneurs' satisfaction of being self-employed. Thus, to enhance entrepreneurial behaviour, the development of individualistic values, such as creativity, autonomy, or striving for a challenging life needs to be instilled early in an individual's life, for example in schools and in the family.

Differences do exist between mature and transition economies. Specifically, we found significant country differences with respect to the relationship between enterprise performance and the founder's satisfaction with being self-employed. In transition economies, organizational outcomes have a stronger impact on entrepreneurs' satisfaction with their occupational choice. Also, important disparities were noted in the motivation structure of new venture creation.

7 It should be noted that collectivism is not viewed as the opposite to individualism, but as a further disposition of the individual. As individualism is associated with a free-market economy, collectivism is an attribute of a communist society and a centrally-planned economy. 
Poland and Slovenia have significantly more necessity-driven entrepreneurs than does Austria, reflecting distinctive characteristics of the transition process, such as unemployment and the scarcity of resources in private households. Next, we found that the individualistic values of Polish entrepreneurs have a significantly stronger impact on entrepreneurial skills than those of Slovenian and Austrian founders. Also, we observed in the Polish sample a positive effect of individualistic values on enterprise performance. Our results indicate that in less advanced transition economies, where individuals have to cope with resource constraints and sometimes still unstable institutions, the individualistic profile of the entrepreneur remains a crucial factor influencing new venture performance, in contrast to education or industry experience. This supports Bourdieu's thesis that economic analyses of an individual's actions need to be extended to encompass cultural values as well. We also found differences between the transition economies: the more individualistic entrepreneurs of Slovenia express more satisfaction with self-employment than do their Polish counterparts, suggesting that the occupational satisfaction of entrepreneurs in less-developed economies may be strongly influenced by other factors, such as the extent to which career choices are accepted by parents, spouses and friends.

There are some limitations of the study that have to be considered. First, we did not include tacit knowledge gained as a child of entrepreneurial parents from the analysis. Self-employed parents usually provide their children with knowledge on how to organize and lead a firm. That kind of knowledge is to a certain degree shared at an unconscious level, but - according to cultural capital theory - it might constitute a valuable resource in cases where the child chooses to be self-employed in the future. We reached the conclusion, however, that including such a variable in models is primarily reasonable in economies with a long tradition of entrepreneurship. But post-communist countries with the relatively short history of entrepreneurship might not be a suitable environment to prove how such family-embeddedness affects new venture performance. Second, we did not include personality traits in the study. Though they might be underpinned under the category "incorporated cultural capital", in our research we focused upon enduring dispositions, which are more linked to the socioanthropological understanding of culture. In this cultural sense, attention is given to implicit and explicit patterns of meanings and practices distributed throughout the context in which an individual participates, and how these guide individuals' behavior (Markus/Hamedani 2007: 12). This understanding of culture is close to the Bourdieurian philosophy and pertains to a larger extent to cultural values than to psychological traits. In addition to that, socioanthropological variables like cultural values still remain under-researched in the entrepreneurship context, in particular at the level of economic actor (Bruton et al. 2008). 
Our findings support the assumption that entrepreneurial performance in the early phases of venture emergence is culture-driven. Several implications arise for future research. First, and most importantly, in order to deepen our knowledge of the role of culture in entrepreneurial performance, we need to avoid "the mistaken assumption that individualist and collectivist values each form coherent syndromes that are opposed to one another" (Schwartz 1990: 151) and that only individualism is positively associated with entrepreneurial behavior. Central and Eastern Europe, still in transition toward free-market economies, may remain influenced by the more collectivistic values that prevailed during communism, such as the role of extended family and community, strong reciprocal relationships based on mutual favors, and a preference for equality. Therefore, new venture success in less individualistic cultures may be influenced more strongly by collectivistic values. Second, if we take the more psychological understanding of culture, it is valuable to consider the psychological traits in the cultural capital models, because they are both inherited and learned (Hofstede 1991). Third, due to the heterogeneity among post-communist countries, studies in other transition countries at different stages of economic and political development are needed. Finally, understanding the role of cultural values in entrepreneurial processes may require extending quantitative research designs to include more inductive, qualitative approaches (Dana/Dana 2005).

\section{Acknowledgements}

The paper has been presented at the 2011 Annual Meeting of the Academy of Management in San Antonio, Texas. We would like to express thanks to the audience for valuable suggestions. We would also like to thank two anonymous reviewers for their constructive comments. Finally, we are grateful for the financial support from the Warsaw School of Economics, the Austrian Agency for International Cooperation in Education and Research, and the Verein zur Förderung der Wirtschaftswissenschaften at the Klagenfurt University, which allowed us to conduct the international survey.

\section{References}

Aidis, R./ Sauka, A. (2005): Entrepreneurship in a Changing Environment: Analyzing the Impact of Transition Stages on SME Development, in: Welter, F. (ed.): Challenges in Entrepreneurship and SME Research, Brussels: European Council of Small Business and Entrepreneurship, 5-36.

Becker, G. (1993): Human Capital. A Theoretical and Empirical Analysis with Special Reference to Education (3. ed.). Chicago The University of Chicago Press.

Bosma, N. and Harding, R. (2007): Global Entrepreneurship Monitor: GEM 2006 Summary Results. Babson/London: Babson College and London Business School. 
Bosma, N./ Jones, K./ Autio, E./ Levie, J. (2008): Global Entrepreneurship Monitor: GEM 2007 Executive Report. Babson/London: Babson College and London Business School.

Bosma, N./ Van Praag, M./ Thurik, R./ De Wit, G. (2004): The Value of Human and Social Capital Investments for the Business Performance of Startups, in: Small Business Economics, 23, 3, 227-236.

Bourdieu, P. (1986): The Forms of Capital, in: Richardson, J.G. (ed.): Handbook of Theory and Research for Sociology of Education, Westport/Connecticut: Greenwood Press, 241-258.

Bourdieu, P. (1991): Language and Symbolic Power. Cambridge/MA: Harvard University Press.

Brown, D. (2002): The Role of Work and Cultural Values in Occupational Choice, Satisfaction, and Success: A Theoretical Statement, in: Journal of Counselling and Development, 80,1, 48-56.

Brüderl, J./ Preisendörfer/ Ziegler, R. (1998): Der Erfolg neugegründeter Betriebe (2. ed.), Berlin: Duncker and Humblot.

Bruton, G.D./ Ahlstrom, D./ Obloj, K. (2008): Entrepreneurship in Emerging Economies: Where Are We Today and Where Should the Research Go in the Future, in: Entrepreneurship Theory and Practice, 32,1, 1-14.

Chandler, G.N./ Hanks, S.H. (1994): Founder Competence, the Environment, and Venture Performance, in: Entrepreneurship Theory and Practice, 18, 3, 77-90.

Chandler, G.N./ Hanks, S.H. (1998): An Examination of the Substitutability of Founders' Human and Financial Capital in Emerging Business Ventures, in: Journal of Business Venturing 13, 5, 353-369.

Clausen, J.A. (1968): Socialization and Society. Boston/MA: Little Brown and Company.

Coleman, J.S. (1991): Grundlagen der Sozialtheorie (Band 1). München: Oldenbourg Verlag.

Cooper, A.C./ Gimeno-Gascon, F.J./ Woo, C.Y. (1994) Initial Human and Financial Capital as Predictors of New Venture Performance, Journal of Business Venturing, 9, 5, 371395.

Dana, L.P./ Dana, T.E. (2005): Expanding the Scope of Methodologies Used in Entrepreneurship Research, in: International Journal of Entrepreneurship and Small Business, 2, 1, 79-88.

Danis, W.M. (2003): Differences in Values, Practices, and Systems among Hungarian and Western Expatriates: An Organizing Framework and Typology, in: Journal of World Business, 38, 3, 224-244.

Davidsson, P./ Honig, B. (2003): The Role of Social and Human Capital among Nascent Entrepreneurs, in: Journal of Business Venturing, 18, 3, 301-331.

Dean, A./ Kretschmer, M. (2007): Can Ideas Be Capital? Factors of Production in the Postindustrial Economy: A Review and Critique, in: Academy of Management Review, 32, 2, 573-594. 
Dibbern, J./ Chin, W.W. (2005): Multi-Group Comparison: Testing a PLS Model on the Sourcing of Application Software Services across Germany and the U.S.A. Using a Permutation Based Approach, in: Bliemel, F./Eggert, A./Fassott, G./Henseler, J. (eds.): Handbuch PLS-Pfadmodellierung: Methode, Anwendung, Praxisbeispiele, Stuttgart: Schäffer-Pöschel, 139-159.

Dunkelberg, W.C./ Cooper, A.C./ Woo, C./ Dennis, W. (1987): New Firm Growth and Performance, Frontiers of Entrepreneurship Research, Wellesley/MA: Babson College.

Fornell, C./ Larcker, D.F. (1981): Evaluating Structural Equation Models with Unobservable Variables and Measurement Errors, in: Journal of Marketing Research, 18, 1, 39-50.

Garnsey, E. (1998): A Theory of the Early Growth of the Firm, in: Industrial and Corporate Change, 7, 3, 523-56.

Gartner, W.B. (1985): A Conceptual Framework for Describing the Phenomenon of New Venture Creation, in: Academy of Management Review, 10, 4, 696-706.

Hansmann, K.-W./ Ringle, C.M. (2004): SmartPLS Benutzerhandbuch. Hamburg: Universität Hamburg.

Hofstede, G. (1991): Cultures and Organizations: Software of the Mind. Intercultural Cooperation and Its Importance for Survival. London: McGraw-Hill International.

Hulland, J. (1999): Use of Partial Least Squares PLS in Strategic Management Research: A Review of Four Recent Studies, in: Strategic Management Journal, 20, 2, 195-204.

Hunt, S./ Levie, J. (2003): Culture as Predictors of Entrepreneurial Activity, Frontiers of Entrepreneurship Research, Wellesley/MA: Babson College.

Kennedy, J./ Drennan, J. (2001): A Review of the Impact of Education and Prior Experience on New Venture Performance, in: Entrepreneurship and Innovation 2, 3, 153-169.

Kilby, R.W. (1993): The Study of Human Values. Lanham: University Press of America.

Kirkman, B.L./ Shapiro, D.L. (2001): The Impact of Cultural Values on Job Satisfaction and Organizational Commitment in Self-Managing Work Teams: The Mediating Role of Employee Resistance, in: Academy of Management Journal, 44, 3, 557-569.

Klandt, H. (1984): Aktivität und Erfolg des Unternehmensgründers. Eine empirische Analyse unter Einbeziehung des mikrosozialen Umfeldes. Bergisch Gladbach: Josef Eul Verlag.

Krafft, M./Götz, O./Liehr-Gobbers, K. (2005): Die Validierung von Strukturgleichungsmodellen mit Hilfe des Partial-Least-Squares PLS-Ansatzes, in: Bliemel, F./Eggert, A./Fassott, G./Henseler, J. (eds.): Handbuch PLSPfadmodellierung: Methode, Anwendung, Praxisbeispiele, Stuttgart: SchäfferPöschel, 71-86.

Lee, S.M./Peterson, S.J. (2000): Culture, Entrepreneurial Orientation, and Global Competitiveness, in: Entrepreneurial Orientation, 35, 4, 401-416.

Lengyel, G. (2002): Social Capital and Entrepreneurial Success: Hungarian Small Enterprise between 1993 and 1996, in: Bonell, V.E/Gold, T.B. (eds.): The New Entrepreneurs of Europe and Asia, Armonk/NY: M.E. Sharpe, 256-277. 
Lindeman, M./Verkasado, M. (2005): Measuring Values with the Short Schwartz's Value Survey, in: Journal of Personality Assessment, 85, 2, 170-178.

Lyles, M.A./Saxton, T./Watson, K. (2004): Venture Survival in a Transitional Economy, in: Journal of Management, 30, 3, 351-375.

Markus, H.R./Hamedani, M.Y.G. (2007): Socio-Cultural Psychology: The Dynamic Interdependence among Self Systems and Social Systems, in: Kitayama, S./Cohen, D. (eds.): Handbook of Cultural Psychology, New York and London: The Guilford Press, 3-39.

Matlay, H. (2001): Entrepreneurial and Vocational Education and Training in Central and Eastern Europe, in: Education + Training, 43, 8-9, 395-404.

Mitchell, R.K./Smith, B./Seawright, K.W./Morse, E.A. (2000): Cross-Cultural Cognitions and the Venture Creation Decision, in: Academy of Management Journal, 43, 5, 974994.

Mohr, J./DiMaggio, P. (1995): The Intergenerational Transmission of Cultural Capital, in: Wallace, M. (ed.): Research in Social Stratification and Social Mobility. Greenwich: JAI Press.

Morris, M./Schindehutte, M. (2005): Entrepreneurial Values and the Ethnic Enterprise: An Examination of Six Subcultures, in: Journal of Small Business Management, 43, 4, 453-479.

Münich, D./Svejnar, J./Terrell, K. (2005): Returns to Human Capital under the Communist Wage Grid and During the Transition to a Market Economy, in: The Review of Economics and Statistics, 87, 1, 100-123.

Murphy, G.B./Trailer, J.W./Hill, R.C. (1996): Measuring Performance in Entrepreneurship Research, in: Journal of Business Research, 36, 1, 15-23.

Ndofor, H.A./Priem, R.L. (2005): Forms of Entrepreneurs Capital, Venture Strategy and Performance: The Special Case of Minority Entrepreneurs, in: Academy of Management Best Paper Proceedings.

Orazem, F./Vodopivec, M. (1997): Value of Human Capital in Transition to Market: Evidence from Slovenia, in: European Economic Review, 41, 3-5, 893-903.

Rebernik, M./Tominc, P./Glas, M./ Psenicny, V. (2004): Global Entrepreneurship Monitor 2003. The Slovenian Report. Maribor: Koda Press.

Ritchie, B./Brindley, C. (2005): Cultural Determinants of Competitiveness within SMEs, in: Journal of Small Business and Enterprise Development, 12, 1, 104-119.

Schultz, T.W. (1975): The Value of the Ability to Deal with Disequilibria, in: Journal of Economic Literature, 13, 3, 827-846.

Schwartz, S.H. (1990): Individualism-collectivism: Critique and Proposed Refinements, in: Journal of Cross-Cultural Psychology, 21, 2, 139-157.

Schwartz, S.H. (1992): Universals in the Content and Structure of Values: Theoretical Advances and Empirical Tests in 20 Countries, in: Zanna, M. (ed.): Advances in Experimental Social Psychology, New York: Academic Press, 1-65.

Schwartz, S.H. (1994): Are There Universal Aspects in the Structure and Contents of Human Values?, in: Journal of Social Issues, 50, 4, 19-45. 
Schwarz, E.J./ Wdowiak, M.A. (2006): New Venture Performance in the Transition Economies: A Conceptual Model, in: Galbraith, C.S. and Stiles, C. (eds.): Developmental Entrepreneurship: Risk, Adversity and Isolation, Oxford: Elsevier Science, 89-111.

Schwarz, E.J./ Ehrmann, T./ Breitenecker, R. (2005) Erfolgsdeterminanten junger Unternehmen in Österreich: eine empirische Untersuchung zum Beschäftigtenwachstum, in: Zeitschrift für Betriebswirtschaft, 11, 1077-1098.

Shane, S. (1993): Cultural Influences on National Rates of Innovation, in: Journal of Business Venturing, 8, 1, 59-73.

Shane, S./ Stuart, T. (2002) Organizational Endowments and the Performance of University Start-ups, in: Management Science, 48, 1, 154-170.

Smallbone, D./ Welter, F. (2001) The Distinctiveness of Entrepreneurship in Transition Economies, in: Small Business Economics, 16, 4, 249-262.

Stevenson, H.H. (1999): A Perspective on Entrepreneurship, in: Sahlman, W.A./Stevenson, H.H./Roberts, M.J./Bhide, A. (eds.): The Entrepreneurial Venture, Boston/MA: Harvard Business School Press, 7-22.

Stuart, R.W./ Abetti, A. (1990) Impact of Entrepreneurial and Management Experience on Early Performance, in: Journal of Business Venturing, 5, 3, 151-162.

Sullivan, A. (2001): Cultural Capital and Educational Attainment, in: Sociology, 35, 4, 893912.

Swartz D.L./ Zolberg V.L. (2004): After Bourdieu. Influence, Critique, Elaboration. Norwell/MA: Kulwer Academic.

Tiessen, J.H. (1997): Individualism, Collectivism, and Entrepreneurship: A Framework for International Comparative Research, in: Journal of Business Venturing, 12, 5, 367384.

Timmons, J.A. (2002): New Venture Creation: Entrepreneurship for the $21^{\text {st }}$ Century (5. ed.), Boston: McGraw-Hill/Irwin.

Wasilczuk, J. (2000): Advantageous Competence of Owner/Mangers to Grow the Firm in Poland: Empirical Evidence, in: Journal of Small Business Management, 38, 2, 80-94.

Weinzimmer, L.G./ Nystrom:C./ Freeman, S.J. (1998): Measuring Organizational Growth: Issues, Consequences and Guidelines, in: Journal of Management, 24, 2, 235-262.

Weiss, A. (1995): Human Capital vs. Signalling Explanations of Wages, in: Journal of Economic Perspectives, 9, 4, 133-154.

Wennekers, S./ Thurik, A.R./ Uhlaner, L.M. (2002): Entrepreneurship and Economic Growth: A Macro Perspective, in: International Journal of Enterprise Education, 1, 2, 157-179.

World Bank (ed.) (2006): World Development Indicators Database, Washington. 